Prepared in cooperation with the Bureau of Reclamation

\title{
Gravity Surveys and Depth to Bedrock in the Truxton Basin, Northwestern Arizona
}

Chapter $\mathrm{C}$ of

Geophysical Surveys, Hydrogeologic Characterization, and Groundwater Flow Model for the Truxton Basin and Hualapai Plateau, Northwestern Arizona

Scientific Investigations Report 2020-5017-C

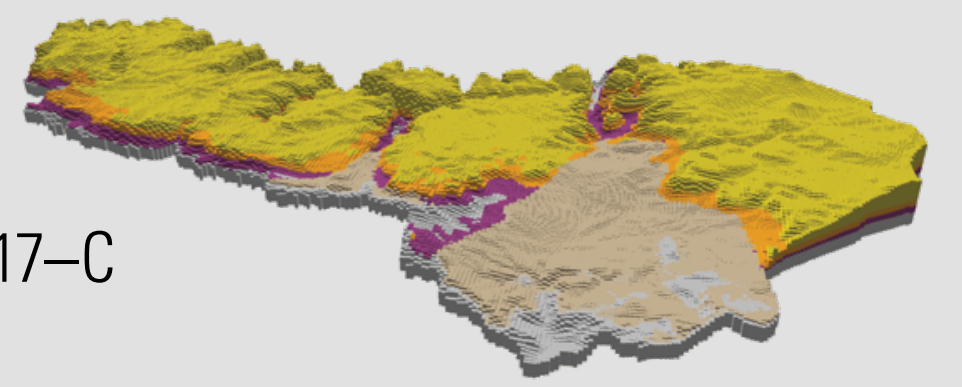

U.S. Department of the Interior U.S. Geological Survey 
Cover photograph. Aerial view west toward the boundary between the Truxton basin and Haulapai Plateau. Flat area in the center and center left of the photograph is Truxton basin. Hilly areas at the bottom and right are part of the Hualapai Plateau. Hilly areas bordering the Truxton basin in the upper left are the Cottonwood Mountains. Photograph by Jon Mason, U.S. Geological Survey, 2015.

Cover inset. Three-dimensional perspective of the Truxton Basin Hydrologic Model viewing the Truxton basin and surrounding area from the south. 


\section{Gravity Surveys and Depth to Bedrock in the Truxton Basin, Northwestern Arizona}

By Jeffrey R. Kennedy

Chapter C of

Geophysical Surveys, Hydrogeologic Characterization, and Groundwater Flow Model for the Truxton Basin and Hualapai Plateau, Northwestern Arizona

Edited by Jon P. Mason

Prepared in cooperation with the Bureau of Reclamation

Scientific Investigations Report 2020-5017-C 


\title{
U.S. Department of the Interior DAVID BERNHARDT, Secretary
}

\author{
U.S. Geological Survey \\ James F. Reilly II, Director
}

\section{U.S. Geological Survey, Reston, Virginia: 2020}

For more information on the USGS - the Federal source for science about the Earth, its natural and living resources, natural hazards, and the environment-visit https://www.usgs.gov or call 1-888-ASK-USGS (1-888-275-8747).

For an overview of USGS information products, including maps, imagery, and publications, visit https://store.usgs.gov.

Any use of trade, firm, or product names is for descriptive purposes only and does not imply endorsement by the U.S. Government.

Although this information product, for the most part, is in the public domain, it also may contain copyrighted materials as noted in the text. Permission to reproduce copyrighted items must be secured from the copyright owner.

Suggested citation:

Kennedy, J.R., 2020, Gravity surveys and depth to bedrock in the Truxton basin, northwestern Arizona, chap. C of Mason, J.P., ed., Geophysical surveys, hydrogeologic characterization, and groundwater flow model for the Truxton basin and Hualapai Plateau, northwestern Arizona: U.S. Geological Survey Scientific Investigations Report 20205017, 10 p., https://doi.org/10.3133/sir20205017C.

Associated data for this publication:

Kennedy, J.R., 2020, Gravity data from the Truxton area, northwestern Arizona: U.S Geological Survey data release, https://doi.org/10.5066/P9ONSNAH.

ISSN 2328-0328 (online) 


\section{Contents}

Abstract
Introduction.
Methods
Data Collection
Inversion
Results
References Cited

\section{Figures}

1. Map showing the geology of the study area and gravity station locations in and near Truxton valley, northwestern Arizona

2. Scatterplot showing measured gravity values versus gravity values at nearby stations obtained from the National Geodetic Survey gravity database

3. Map showing the isostatic gravity anomaly and the surface extent of basin-fill sediments in the Truxton area, northwestern Arizona.

5. Map showing depth to bedrock measured in boreholes in the Truxton area, northwestern Arizona, and modeled depth-to-bedrock contours based on gravity data....7

4. Cross-sectional profile showing the density contrast used to simulate basin-fill sediment and basement density heterogeneity near Truxton, northwestern Arizona..........7

6. Maps of observed gravity, simulated gravity, and their difference in the Truxton valley area, northwestern Arizona

7. Map showing depth to bedrock inferred from gravity data in the Truxton valley area, northwestern Arizona.. 


\section{Abbreviations}

$\begin{array}{ll}\mathrm{cm} & \text { centimeters } \\ \mathrm{DC} & \text { direct current } \\ \mathrm{g} / \mathrm{cm}^{3} & \text { grams per cubic centimeter } \\ \mathrm{GPS} & \text { Global Positioning System } \\ \text { GRS80 } & \text { Geodetic Reference System of 1980 } \\ \mathrm{km} & \text { kilometers } \\ \mathrm{m} & \text { meters } \\ \mathrm{mGal} & \text { milligals } \\ \text { NGS } & \text { National Geodetic Survey }\end{array}$




\title{
Gravity Surveys and Depth to Bedrock in the Truxton Basin, Northwestern Arizona
}

\author{
By Jeffrey R. Kennedy
}

\section{Abstract}

The volume of available groundwater and the effect of groundwater pumping in an alluvial basin is influenced in part by the shape and depth of the basin boundary, which commonly consists of low-permeability bedrock. To better understand the shape and depth of basin fill in the Truxton valley in Arizona, new gravity data were collected at 149 stations in 2017 and 2018. These data, combined with historical data, show a gravity low consistent with deep basin fill near the community of Truxton, west of the Hurricane Fault, which crosses the study area from northeast to southwest. Depth to bedrock was estimated quantitatively through a three-dimensional gravity inversion, a process that identifies the most likely position of a contact between two units with different densities (in this case, high-density bedrock and low-density basin-fill material). Maximum basinfill thickness near Truxton is about 500 meters (m). East of the Hurricane Fault, basin fill is generally thin (less than $100 \mathrm{~m}$ ) and groundwater availability within basin-fill material in this area is likely limited. Few boreholes exist in the study area, but depths to bedrock are consistent with geologic logs from boreholes east and west of Truxton.

\section{Introduction}

Earth's surface gravity (the gravitational acceleration) varies based on elevation (that is, the distance from the Earth's center of mass) and the density of the subsurface. For example, areas underlain by relatively low-density material, such as alluvial basin fill, will generally have lower gravity than areas underlain by higher density rocks, such as limestone or granite. Therefore, information about the distribution of geologic units can be obtained by measuring the spatial gravity field. For this study, gravity surveys targeted the depth to bedrock of the alluvial basin (Truxton basin) surrounding Truxton, Arizona, and the extent of the Hurricane Fault southwest of Peach Springs, Arizona.

In alluvial basins such as the Truxton basin, a distinct density contrast typically exists between low-density sedimentary fill, usually between 1.9 and 2.3 grams per cubic centimeter $\left(\mathrm{g} / \mathrm{cm}^{3}\right)$, and high-density bedrock, usually about $2.67 \mathrm{~g} / \mathrm{cm}^{3}$, which underlies the fill and crops out in the surrounding mountain ranges. This causes a low-gravity anomaly ("gravity low") in the center of the alluvial basin relative to the areas of bedrock. The thickness of sedimentary fill is proportional to the difference in gravity between the basin center and adjacent bedrock. By taking measurements throughout the basin and on bedrock, the general shape of the basin (that is, the surface representing the top of bedrock) can be determined.

The gravity method has been used successfully in many studies of alluvial basins in the Basin and Range Province throughout the southwestern United States (Saltus and Jachens, 1995). In the adjacent basin to the west of the study area, Hualapai Valley, a bedrock depth down to 4,300 meters (m) was estimated from gravity data (Ivanich and Conway, 2009; Truini and others, 2013). A distinct basin in the Truxton valley is not identified on a generalized depth-to-bedrock map covering the state of Arizona (Richard and others, 2007). However, the map is based on relatively sparse data and focuses on the more prominent basins of the Basin and Range Province to the west and south. Although most depth-to-bedrock studies in the southwestern United States were carried out in fault-bounded basins of the Basin and Range Province, sedimentary fill bounded by paleochannel topography carved in bedrock should produce a similar gravity signal.

The study area consists of Paleozoic and Cenozoic sedimentary and volcanic units underlain by Proterozoic basement rocks (see Mason and others [2020] for more information on the geology of the study area). Because the density contrasts within the Proterozoic, Paleozoic, and Cenozoic units are generally minor, and information on subsurface density absent, they are treated as a single unit in the gravity inversion. That is, the subsurface model for the purpose of gravity modeling consists of two units: high-density bedrock, including Proterozoic, Paleozoic, and Cenozoic units; and low-density sedimentary basin fill (subdivided into two units). Differentiating between units within the bedrock (for example, identifying the Muav Limestone-Bright Angel Shale contact) is not possible with the data available.

Complicating the density-based interpretation is the presence of low-density Cenozoic volcanic units, including the Peach Spring Tuff (Nielson and others, 1990), primarily in the western part of the study area (unit Tv, fig. 1). Based on rock sample density measurements, these units are essentially indistinguishable from low-density basin fill, and are interbedded with basin-fill material. Therefore, the gravity inversion and interpretation (as well as the groundwater-flow model of Knight [2020]) include low-density volcanic units as basin-fill material. Other Cenozoic 




Figure 1. Map showing the geology of the study area and gravity station locations in and near Truxton valley, northwestern Arizona. Geologic units from Richard and others (2000) and Hurricane Fault location from Hirschberg and Pitts (2000). 
volcanic units, such as basalt in the eastern part of the study area, have higher density and are indistinguishable from Paleozoic and Proterozoic rocks.

\section{Methods}

Gravity data were obtained from the National Geodetic Survey (1999) and additional data were collected for this study (fig. 1). Standard gravity field methods (Telford and others, 1990) were used to collect data at 149 stations over 4 weeks in 2017 and 2018 (Kennedy, 2020). Standard reductions (Hinze and others, 2005) to account for gravity differences caused by station elevation and surrounding terrain were applied. Regional gravity variation was removed using published maps (Sweeney and Hill, 2001). The resultant gravity anomaly, after applying all reductions, should reflect only the density contrast between low-density sedimentary fill and high-density bedrock, and heterogeneous density variation within each unit. This gravity anomaly was interpreted using geophysical inversion through which a reasonable subsurface model was created that accurately simulates the measured gravity field.

\section{Data Collection}

Gravity data were collected at 149 stations using a ZLS Corporation Burris relative-gravity meter and a Micro-g Lacoste, Inc., A-10 absolute-gravity meter. Drift correction for relative-gravity surveys was carried out using a combination of looping (returning to a base station periodically) and traversing between absolute-gravity stations (because gravity is known at each absolute-gravity station, relative-gravity meter drift can be interpolated at the intermediate stations).

Global Positioning System (GPS) data were collected using one GPS receiver as a base station and a second receiver to locate each gravity station. Seven locations were used as base stations, depending on the area where relative-gravity surveys were being carried out. Base station occupations were 6 hours or longer and positioned in the North American Datum of 1983 (2011) epoch 2010.00 reference frame using the National Geodetic Survey Online Positioning User Service. Baseline solutions between the GPS receiver at each gravity station and the base station were processed using Trimble Business Center software. At least 8 minutes of GPS data were collected at each relative-gravity station and at least 20 minutes at each absolute-gravity station. Estimated vertical accuracy is about 5 centimeters $(\mathrm{cm})$, equivalent to a gravity range of about 0.015 milligals ( $\mathrm{mGal}$ ).

Rock samples in the form of surface cobbles (10 to $20 \mathrm{~cm}$ in diameter) were collected for density analysis in the vicinity of absolute-gravity measurements. Eleven samples of Redwall Limestone, the dominant Paleozoic bedrock unit in the study area, and 11 Peach Spring Tuff samples, the dominant volcanic rock, were collected. Limestone samples were collected in the eastern part of the gravity network and to the north near the Music Mountains. Volcanic samples were collected in the southwestern part of the gravity network. Rock densities were determined using a water immersion method to determine volume and an electronic balance to determine mass. The average density of limestone samples was $2.67 \pm 0.09 \mathrm{~g} / \mathrm{cm}^{3}$ $( \pm 1$ standard deviation) and the average density of volcanic samples was $1.97 \pm 0.37 \mathrm{~g} / \mathrm{cm}^{3}$.

Absolute- and relative-gravity data were combined in a least-squares network adjustment (Hwang and others, 2002). The gravity anomaly was calculated by subtracting the theoretical gravity value for the Geodetic Reference System of 1980 (GRS80) ellipsoid along with standard corrections for elevation (free air) and the Bouguer slab correction (Hinze and others, 2005). Terrain corrections were calculated to 167 kilometers $(\mathrm{km})$ distance assuming $2.67 \mathrm{~g} / \mathrm{cm}^{3}$ terrain density from elevation data obtained from The National Map (U.S. Geological Survey, 2017). Between 0 and $1 \mathrm{~km}$, corrections were calculated from elevation data sampled on an 8-m grid. Between 1 and $167 \mathrm{~km}$, corrections were calculated from elevation data sampled on a 740-m grid. All corrections were calculated using QCTool software (Petros Eikon, Inc., 2018). Additional details are provided in an accompanying data release (Kennedy, 2020).

Complete Bouguer anomaly values from the National Geodetic Survey (NGS) and U.S. Geological Survey datasets were compared to identify consistency between the two datasets. The NGS data were compiled from several different surveys, and were collected using only relative-gravity meters, as compared to the combination of absolute- and relativegravity data newly collected for the project. Therefore, the NGS data are likely less accurate and (or) tied to a different gravity datum than the newly collected data. Thirteen stations in the NGS dataset located within $500 \mathrm{~m}$ of a new station were identified. A plot of the measured data versus the NGS data shows a small bias between the two datasets. Between the range of gravity-anomaly values present in the study area, -149 to $-165 \mathrm{mGal}$, the bias varies between 1.6 and $1.0 \mathrm{mGal}$ (fig. 2). At 12 of the 13 station pairs, the NGS value was greater (less negative) than the newly corrected value. To account for this bias, a correction factor based on a least-squares regression was applied to the NGS data (fig. 2).

Gravity interpretation involves several steps to remove influencing factors that are not related to the target of interest (in this study, the thickness of basin-fill sediments). First, field data are corrected for time-varying factors, the most important of which is the effect of solid-Earth tides that deform the Earth on daily and twice-daily cycles. Next, the free-air correction is applied to account for the variation in gravity with elevation (weakens as the distance to the Earth's center of mass increases). The Bouguer correction (Hinze and others, 2005) accounts for the gravitational attraction of the mass between the station elevation and the reference datum elevation (typically zero, or sea level). Finally, terrain corrections account for the topography surrounding the gravity station; if a station is next to a hill (nearby mass above the station elevation) or a depression (absence of mass below the station elevation), the observed gravity value will be less than if it were on a flat plain.

After applying these standard corrections, the resultant complete Bouguer anomaly reflects both shallow density variations (including low-density basin fill) and deeper, regional 


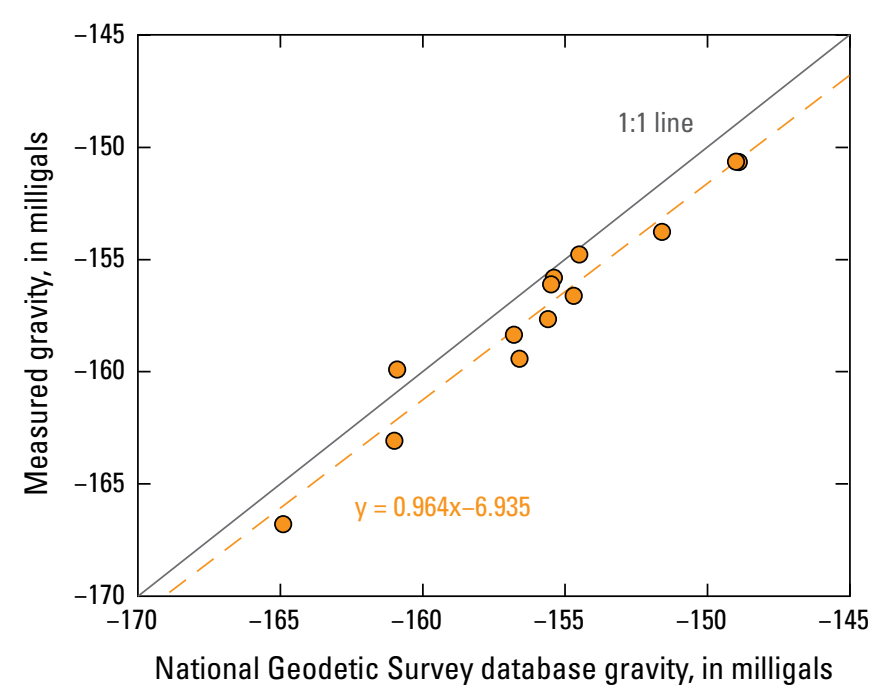

Figure 2. Scatterplot showing measured gravity values versus gravity values at nearby stations obtained from the National Geodetic Survey gravity database.

variation. The study area is located at the western boundary of the Colorado Plateau, where the complete Bouguer anomaly varies from relatively high in the west to relatively low in the east over a distance of several hundred kilometers (Mickus and James, 1991). The isostatic anomaly is a regional gravity field that accounts for this gravity variation and is subtracted from the complete Bouguer anomaly to determine the isostatic residual. It represents the longwavelength density contrasts deeper in the subsurface, related to isostatic compensation of elevated land masses; these contrasts are unrelated to the gravity anomaly caused by low-density basin sediments and more shallow heterogeneity in bedrock units. To calculate the isostatic residual, first the regional trend (Sweeney and Hill, 2001) was subtracted from the complete Bouguer anomaly data (observed gravity values after applying standard corrections). Then, anomaly values were gridded on a 500-m grid using the minimum curvature method (Mira Geoscience Ltd., 2019). The complete Bouguer anomaly and isostatic residual data are available in digital form in the accompanying data release (Kennedy, 2020).

\section{Inversion}

Gravity-data inversion involves finding a suitable subsurface density model that simulates the observed gravity anomaly. The model consists of layers of different density separated by interfaces. During inversion, the position of the interfaces is adjusted in an iterative process. Each step involves calculating the model-simulated gravity field (the "forward" model), comparing the simulated field to observed data, and making adjustments to the interface position(s) accordingly. Iteration proceeds until an acceptable model is found, based on the accuracy of the gravity data. If the data are considered very precise, iteration will proceed until a very detailed model is constructed that matches the data nearly exactly; if the data have relatively high uncertainty, the inversion will have fewer iteration steps and stop when the simulated field approximately matches the observed data. In addition to adjusting the position of the interfaces, the density within a single layer can be adjusted during the inversion. For this study, the inversion code VPmg was used (Mira Geoscience Ltd., 2019).

One challenge in successful gravity inversion of sedimentary basins is accounting for density heterogeneity within the bedrock unit. If bedrock is perfectly homogeneous, the sedimentary basins will appear as circular (or elongated) gravity lows surrounded by uniform gravity highs. In many realworld studies, however, density heterogeneity exists within the bedrock unit that can produce gravity signals not related to the low-density basin fill. One method used successfully to separate bedrock density heterogeneity is to separately grid the stations on bedrock, then subtract the bedrock-gravity grid from the anomaly grid to remove the bedrock signal (Saltus and Jachens, 1995). For this study, owing to the lack of bedrock gravity stations, a modified approach was taken in which the bedrock density distribution was solved in a separate inversion step carried out in series with the depth-to-bedrock inversion. In this bedrock inversion step, the difference between simulated and observed gravity is calculated only in areas of exposed bedrock (that is, a single anomaly is used in the inversion, rather than separately gridding a basin anomaly and bedrock anomaly).

In gravity inversion, one can identify either the position of a density-contrast interface, or the magnitude of the density contrast across an interface at a known location, but not both. The ideal model would avoid undue influence by (or "overfitting") one or the other. The modeling process proceeded by iteratively inverting (that is, solving for) each property in order. This process is possible because each model property (interface position or density contrast) is uniquely sensitive to the data (for example, bedrock density heterogeneity at depth generally produces a longwavelength signal, compared to small-scale variation possible from the near surface basin-fill/bedrock density contrast), and because, during each inversion step, the resultant model advances towards the optimal model, but an exact model is not solved for directly (if it were, only a single step would be necessary to fit the data exactly). The inversion steps were as follows. First, a starting model was created by estimating the basin geometry from airborne electromagnetic and borehole data. Next, a single bedrock density inversion step was carried out, comparing the model-simulated gravity to observed gravity in areas with bedrock at the land surface. Then, with this improved estimate of bedrock heterogeneity, a single depth-to-bedrock inversion step was carried out to improve the initial estimate obtained from electromagnetic and borehole data. Finally, two additional iterations of the bedrock density and depth-to-bedrock inversion steps were carried out.

Gravity inversion to determine depth to bedrock depends on two primary parameters: the DC shift and the density contrast(s). The DC shift is a constant value (in milligals) added to the simulated gravity values to compensate for uncorrected factors in the processing (DC, meaning direct current, is an analogous term from the field of electronics). For example, in the Truxton area, the maximum observed gravity anomaly is $-1.98 \mathrm{mGal}$ (fig. 3). 


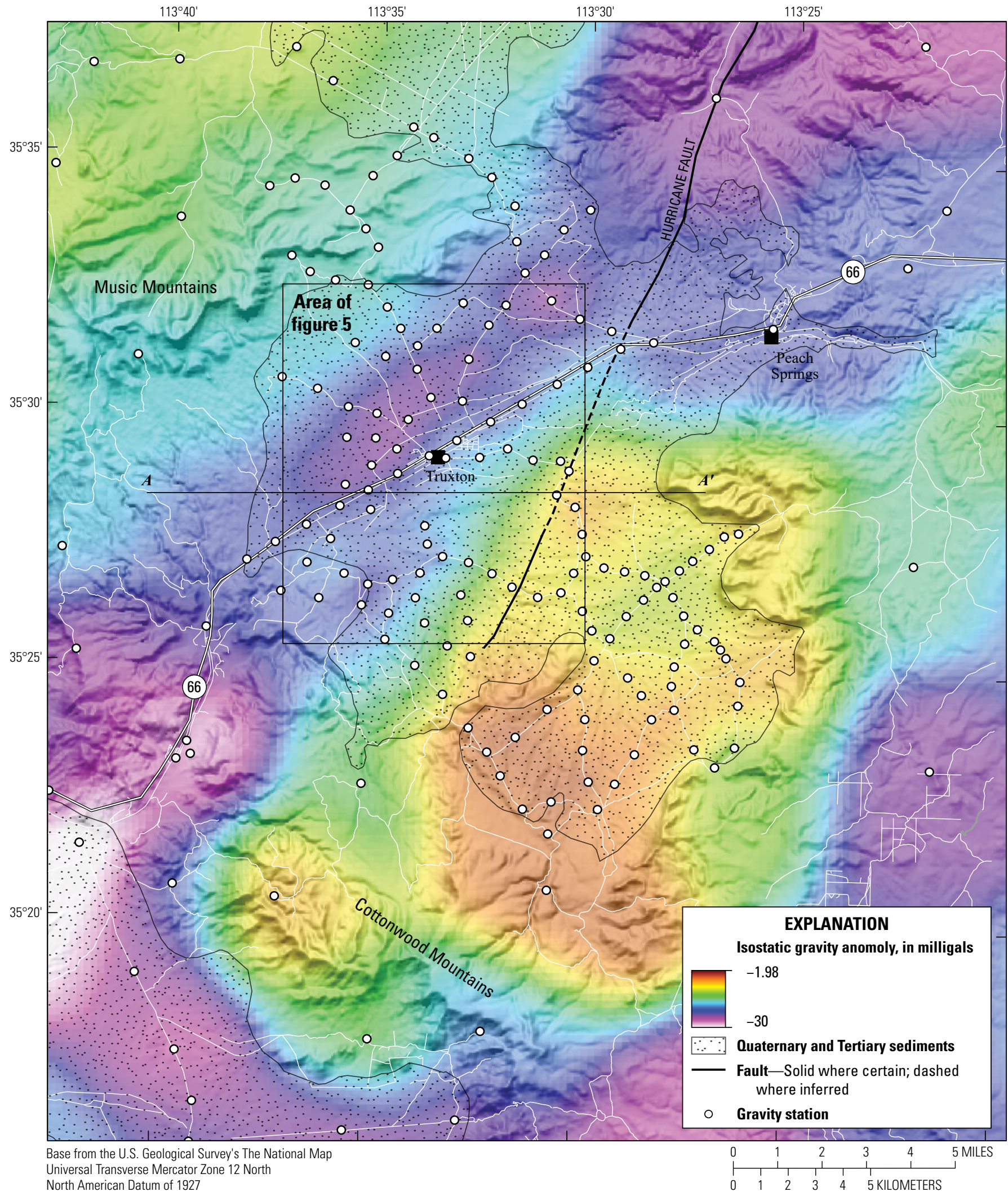

Figure 3. Map showing the isostatic gravity anomaly and the surface extent of basin-fill sediments in the Truxton area, northwestern Arizona. Basin-fill sediment locations are from Hirschberg and Pitts (2000), which differ slightly from those shown in figure 1. Hurricane Fault location is also from Hirschberg and Pitts (2000). 
Because the only property of interest is the thickness of sediment in non-bedrock areas, ideally, any areas of exposed bedrock will have a gravity anomaly equal to zero. In practice, the DC shift is approximately equal to the average bedrock anomaly and is a parameter that can be varied to match the model to the depth to bedrock observed in boreholes.

The second parameter, density contrast, describes the density difference between any two model units. In gravity inversion, only the difference in density, rather than the magnitude, influences the results. Ideally, the density contrast(s) would be determined from borehole geophysical data, but no data are available in the study area. Borehole-gravity data from boreholes in central and southern Arizona indicate a range of possible density contrasts from -0.4 to $-0.7 \mathrm{~g} / \mathrm{cm}^{3}$ (Tucci and others, 1982). Both density contrast and DC shift were varied over a range of feasible values to identify the model that most closely matches observed depths to bedrock in boreholes.

\section{Results}

In gravity studies that target depth to bedrock, the isostatic residual will show a gravity low(s) in the area of basin fill surrounded by higher gravity (that is, a less-negative anomaly) where bedrock is at or near the surface. The isostatic residual in the study area shows the expected gravity low near the town of Truxton (fig. 3). However, other lows to the northeast, southwest, and southeast are in areas of exposed bedrock. This discrepancy arises primarily because of the sparse data in these outlying areas. Other contributing factors are heterogeneity within the Proterozoic bedrock and the widespread presence of low-density Peach Spring Tuff in the western part of the study area.

The isostatic residual (fig. 3) is characterized by a prominent southwest-northeast trending gravity low centered just north of a line from the community of Truxton to the community of Peach Springs, consistent with low-density basin-fill sediments. The low is bounded by gravity highs to the northwest that represent bedrock in the Music Mountains, and to the southeast that represent bedrock either at the surface or shallow subsurface. The gravity high to the southeast of the Hurricane Fault is in an area mapped largely as Tertiary sedimentary deposits, similar to the area around Truxton, but alluvium is likely very thin based on the high gravity values in this area. Therefore, the subsurface extent of basin fill in Truxton valley appears to be smaller than the surface extent, and the thickest intervals of basin fill appear to occupy only a relatively small part of the basin north and west of Truxton - an interpretation supported by airborne electromagnetic data (Ball, 2020). Alternatively, the gravity high southeast of the Hurricane Fault may be caused all or in part by bedrock density heterogeneity, as the inverted bedrock density does indicate higher values in this area (fig. 4). No borehole logs from the area southeast of the Hurricane Fault were available to independently confirm this interpretation.

The southwest-northeast trending gravity low is consistent with a hypothesized paleochannel incised into the Proterozoic basement rocks (Young, 1999; Bills and Macy, 2016). To the southwest, this gravity low extends into the gravity low associated with the Hualapai Valley. Between the Hualapai Valley low and the Truxton basin low is a relative high near the boundary of Quaternary and Tertiary sediments (in light purple, fig. 3; the high is about $-20 \mathrm{mGal}$, still lower than to the northwest and southeast). This high is perhaps associated with low- to intermediate-density (but higher than basin-fill density) Tertiary Peach Spring Tuff deposited within and above the hypothesized paleochannel. To the north and east of Peach Springs, the southwest-northeast trending gravity low becomes more negative, even though sedimentary cover is thin to nonexistent and the topography is dominated by sheer bedrock cliffs in Peach Springs Canyon. The reason for a gravity low in this area of exposed bedrock is

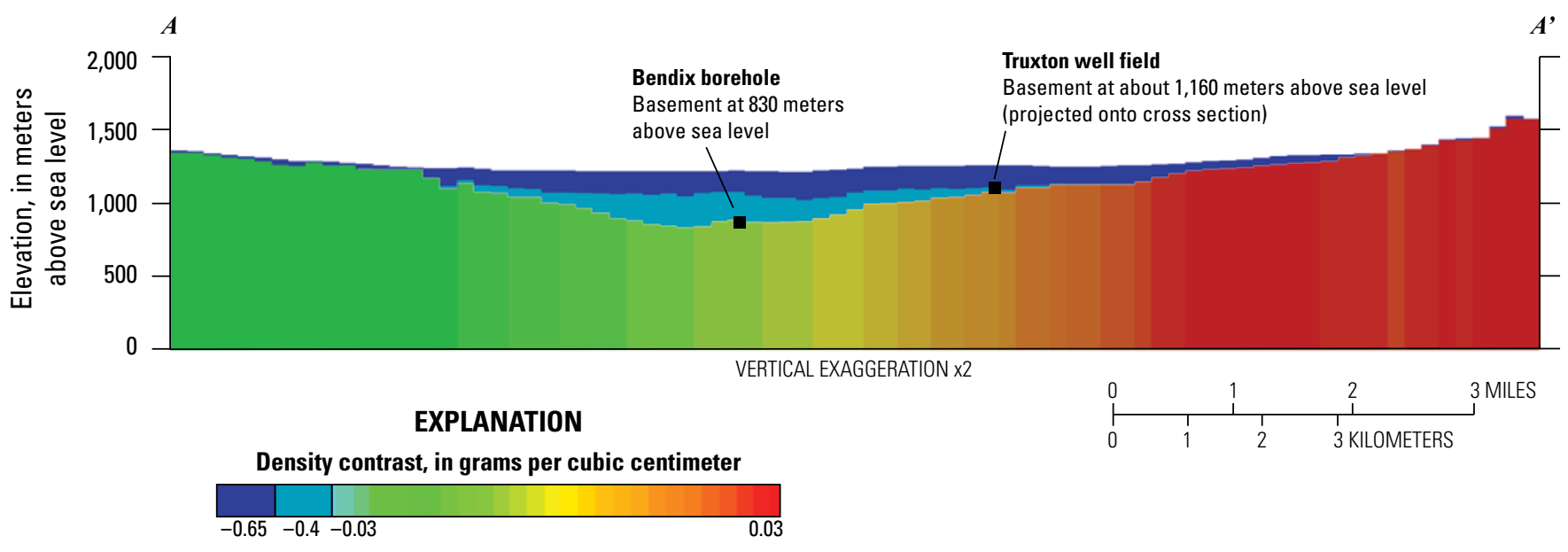

Figure 4. Cross-sectional profile $A-A^{\prime}$ showing the density contrast used to simulate basin-fill sediment and basement density heterogeneity near Truxton, northwestern Arizona. See figure 3 for the location of $A-A^{\prime}$. 
unknown, but, in general, the gravity lows outside the surface extent of Quaternary and Tertiary sediments are poorly defined owing to sparse data. Furthermore, especially to the northeast in Peach Springs Canyon, the gravity terrain correction is significant owing to the nearby Grand Canyon and subject to relatively large uncertainty. Finally, the isostatic residual may be influenced by inaccuracy in the regional isostatic correction: the regional gravity anomaly decreases significantly from west to east in this region (Sweeney and Hill, 2001) and may be inadequately corrected in the processing steps to create the isostatic residual.

Independent information on depth to bedrock is limited primarily to a few boreholes near the community of Truxton. One, the Bendix borehole, was drilled $2 \mathrm{~km}$ west-southwest of Truxton and reached granite basement at $490 \mathrm{~m}$ depth (Young, 1999). Three other closely spaced wells that supply water to the community of Peach Springs, referred to here as the "Truxton well field" (fig. 5; Natural Resources Consulting Engineers, 2011), reached granite at about $190 \mathrm{~m}$. This difference in depth to bedrock, about $300 \mathrm{~m}$ over $4.4 \mathrm{~km}$, is likely related to the position of each borehole relative to the hypothesized southwestnortheast trending paleochannel in Truxton basin. The Bendix borehole was sited to intercept the deepest part of the paleochannel (Richard Young, State University of New York at Geneseo, written commun., 2019), and it appears from the gravity data that the deepest part of the basin is nearby, less than $1 \mathrm{~km}$ north of the borehole. All of the boreholes that reach bedrock are well to the west of the Hurricane Fault, which is therefore probably not the source of the difference in depth to bedrock.

An initial model with a 500-m cell size was constructed using a single density contrast between basin fill and bedrock. Using a reasonable range of density contrasts, and a range of values for DC shift, the gravity inversion was unable to match the observed depth to bedrock in the boreholes - the density contrast that resulted in a model that matched the depth to bedrock in the Bendix borehole overestimated depth in the Truxton well field, and vice versa. To better simulate the more realistic scenario where basin-fill density increases with depth (Tucci and others, 1982), a three-layer model was constructed with density contrasts between an upper and lower basin-fill unit and between the lower basin-fill unit and bedrock (fig. 4). This model was better, but not completely able to match the observed depths to bedrock in boreholes. This discrepancy may arise from unaccounted density heterogeneities in the basement or basin fill, from error in the estimated depth to bedrock in drillers' logs, or from the coarseness of the 500-m model grid relative to the topography of the bedrock surface. Because the depth-to-bedrock surface is steeply dipping in this area, a small offset in borehole location would result in relatively large error in the estimated depth. Depth to bedrock is underestimated by about $50 \mathrm{~m}$ at the Bendix borehole (that is, the modeled depth to bedrock is about $50 \mathrm{~m}$ less than the depth observed in the borehole), and overestimated by about $50 \mathrm{~m}$ at the water supply wells northeast of the town of Truxton (fig. 5).

The predicted gravity from the final subsurface model closely matches the observed data in most of the study area, particularly in the area of exposed Tertiary and Quaternary

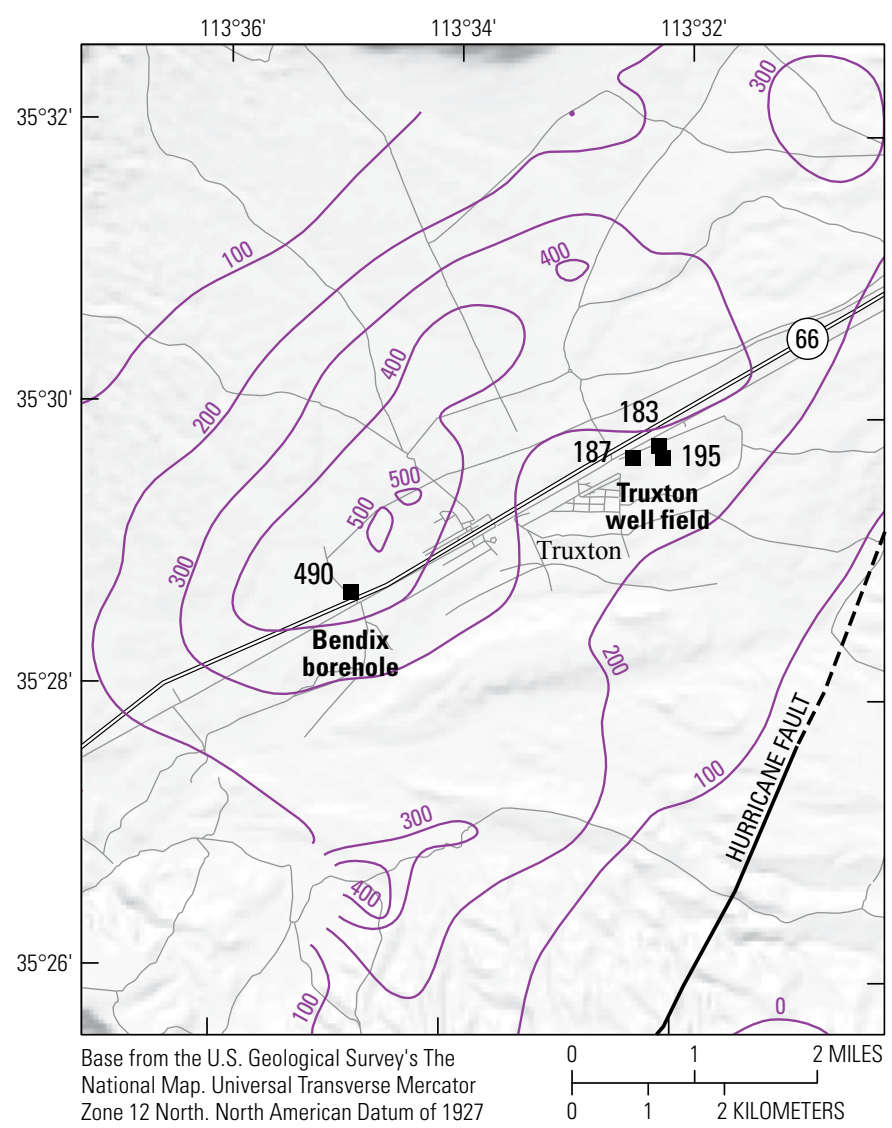

\section{EXPLANATION}

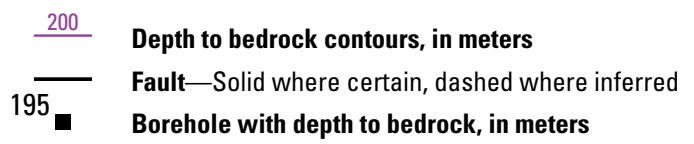

Figure 5. Map showing depth to bedrock measured in boreholes in the Truxton area, northwestern Arizona, and modeled depth-to-bedrock contours based on gravity data. Hurricane Fault location from Hirschberg and Pitts (2000).

sediments (fig. 6). The inversion residual (the difference between the isostatic gravity anomaly and the modeled anomaly; fig. $6 C$ ) is much less than $\pm 1 \mathrm{mGal}$ throughout most of the study area, and areas of high and low residuals (where simulated gravity is too high or too low) are distributed evenly throughout the model area and are not associated with obvious geologic features (fig. 6C), indicating the model is a reasonable simulation. However, gravity interpretation is inherently nonunique and other models may be equally reasonable. The stippled pattern present in the simulated gravity (fig. $6 B$ ), and therefore in the residual (fig. $6 \mathrm{C}$ ), arises from the coarseness of the model grid $(500 \mathrm{~m})$ relative to the steep topography in parts of the study area. These areas are where bedrock is exposed at the surface and do not have significant influence on the depth-to-bedrock estimate. 


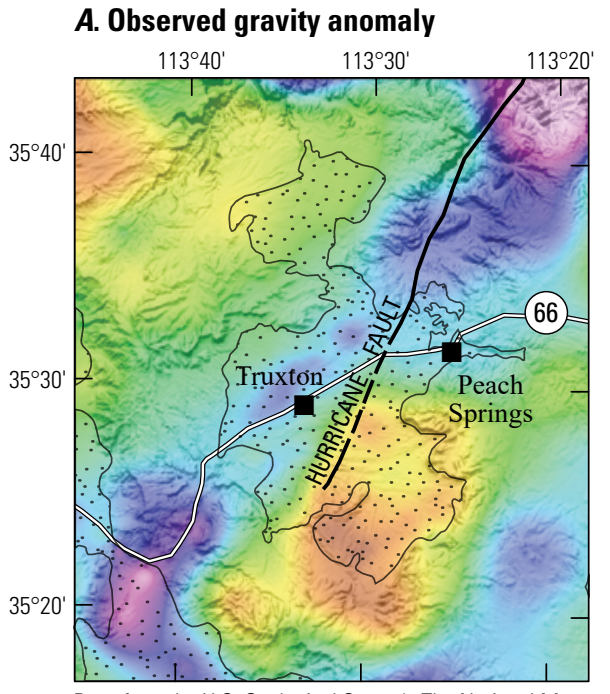

Base from the U.S. Geological Survey's The National Map Universal Transverse Mercator Zone 12 North North American Datum of 1927
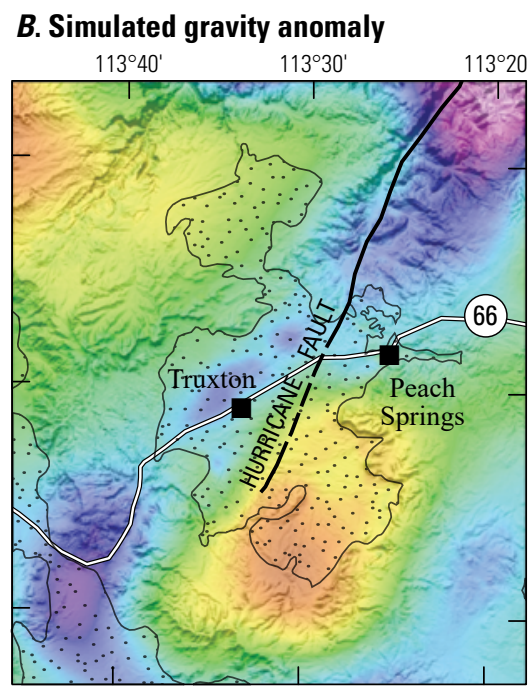

EXPLANATION
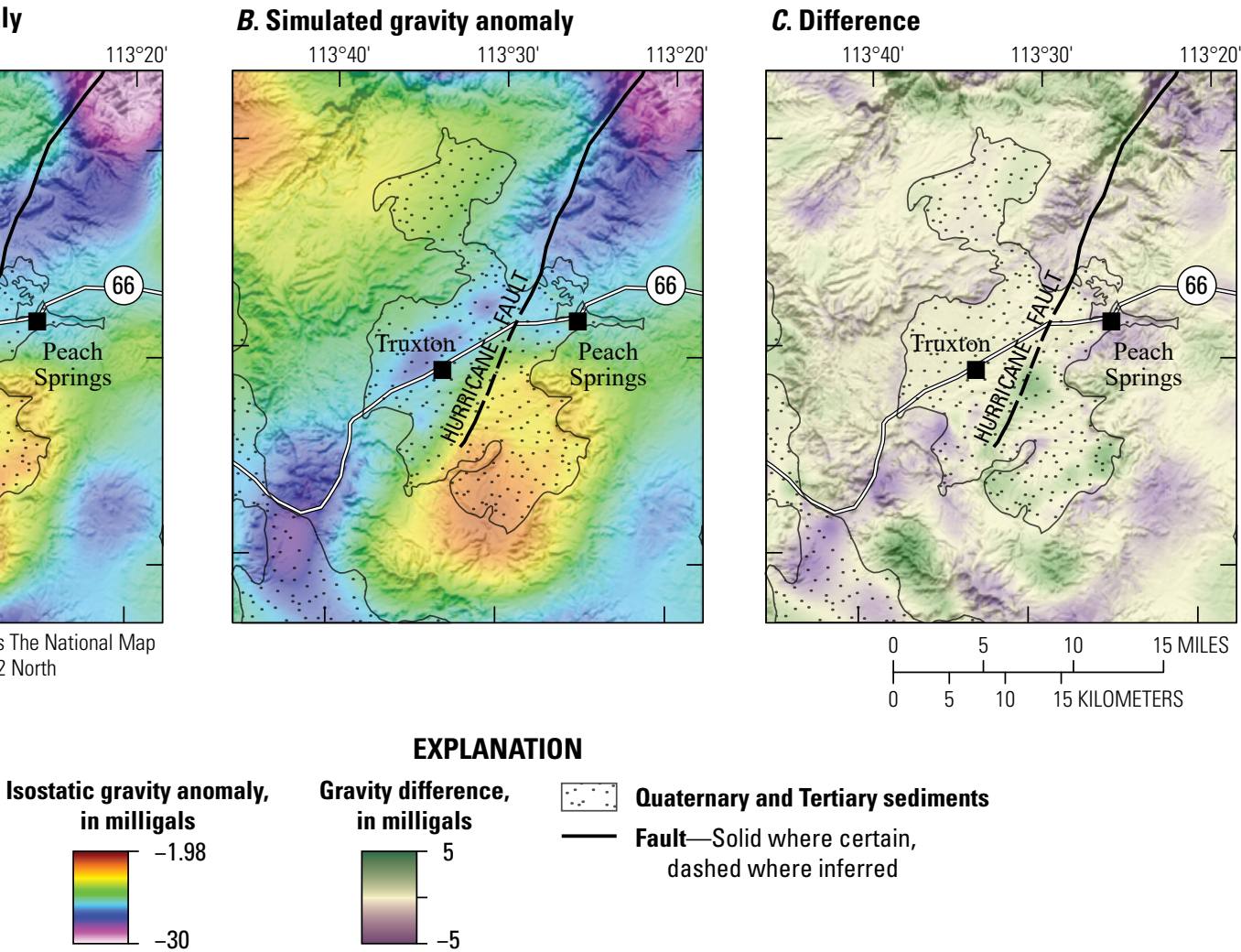

Figure 6. Maps of observed gravity $(A)$, simulated gravity $(B)$, and their difference $(C)$ in the Truxton valley area, northwestern Arizona. Hurricane Fault and basin-fill sediment locations from Hirschberg and Pitts (2000).

The Hurricane Fault, which offsets rocks downward to the west in the central part of the study area, may interfere with the interpretation of depth to bedrock. The fault is clearly visible in the isostatic residual (fig. 3), indicating it offsets units of different density. Faulting, and subsequent removal of bedrock (including Paleozoic units) on the upthrown side of the fault (to the east), could create a gravity anomaly aligned with the Hurricane Fault (fig. 3, center) even in the absence of an alluvial basin. However, to the extent that movement along the Hurricane Fault (in addition to an eroded and later filled paleochannel) has contributed to the existence of the alluvial basin near the town of Truxton, the resultant gravity anomaly is adequately simulated by the model, even without including an explicit fault plane in the density model. Offset on the Hurricane Fault in the study area south of the town of Peach Springs is not well constrained but is estimated to be about $60 \mathrm{~m}$ (Hamblin, 1970).

Depth to bedrock ranges from near $0 \mathrm{~m}$ (bedrock at the land surface) in the Music Mountains north of Truxton basin and in the southern part of the alluvial basin, to a maximum of $500 \mathrm{~m}$ about $2 \mathrm{~km}$ west of the town of Truxton (fig. 7). The basin trends northwest, compared to the north-northwest trend of the Hurricane Fault, suggesting a filled paleochannel origin for the basin as compared to strictly fault displacement. A secondary basin, connected to the deepest basin and about halfway between the towns of Truxton and Peach Springs, about $2 \mathrm{~km}$ north of U.S. Highway 66, extends to a little more than $300 \mathrm{~m}$ depth.
The deepest depth to bedrock southeast of the Hurricane Fault is about $100 \mathrm{~m}$. Outside of the alluvial basins near Truxton and north of U.S. Highway 66, especially near the community of Peach Springs and to the north and southwest of the community of Truxton, depths to bedrock are considered unreliable because of sparse data, lack of borehole control, and geologic units not incorporated in the density model (primarily the Peach Spring Tuff). Owing to the abundant information in the airborne electromagnetic data collected for the project, the inclusion of additional complexity in the density model was not warranted.

\section{Conclusions}

Gravity data in Truxton basin are consistent with an alluvial basin in the central part of the basin, near the community of Truxton. Gravity in this area is lower than the surrounding area, which, when considered in context of the geology, indicates low-density basin fill surrounded by higher density bedrock. Using reasonable assumptions about the density of basin fill, measurements of bedrock and volcanic tuff density, and information about bedrock depth from boreholes, geophysical inversion was used to create a reasonable layered model that simulates the measured gravity anomaly.

The maximum depth to bedrock in the Truxton basin is approximately $500 \mathrm{~m}$ at a distance of less than $1 \mathrm{~km}$ north 


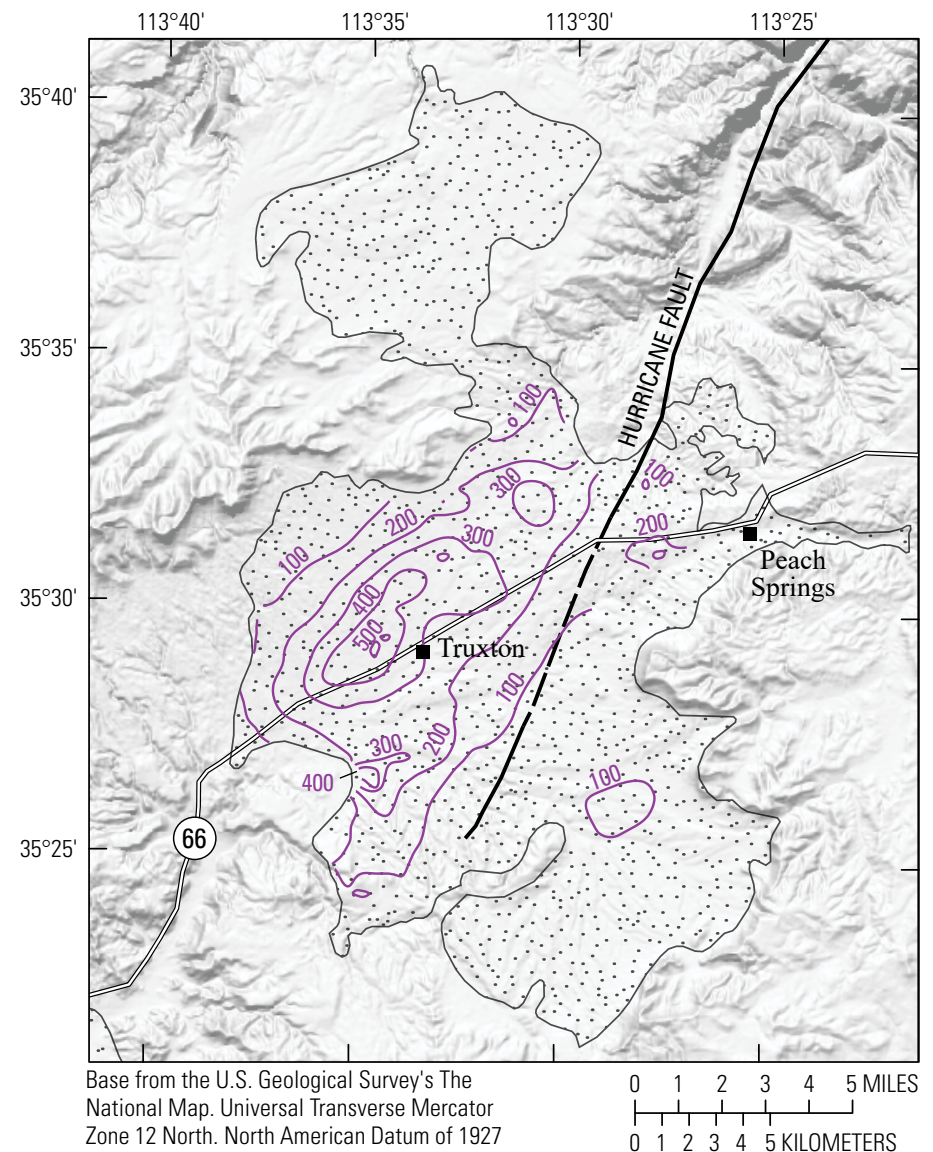

EXPLANATION

Quaternary and Tertiary sediments

200 Depth to bedrock contours, in meters

Fault-Solid where certain, dashed where inferred

Figure 7. Map showing depth to bedrock inferred from gravity data in the Truxton valley area, northwestern Arizona. Hurrican Fault and basin-fill sediment locations from Hirschberg and Pitts (2000).

of an exploration borehole drilled in the 1970s near the town of Truxton (Bendix borehole) and about $2 \mathrm{~km}$ west of the community of Truxton. In the Truxton basin, the extent of deep basin fill (greater than $50 \mathrm{~m}$ ) is much smaller than the extent of mapped alluvium. In particular, the gravity anomaly in the area southeast of the Hurricane Fault, in the southern part of Truxton basin, is consistent with thin alluvium or basin fill and there is likely little water stored in sedimentary deposits in the area.

The gravity data show a clear southwest-northeast gravity low consistent with a previously hypothesized paleochannel (Young, 1999; Bills and Macy, 2016). Subparallel to this trend, to the southeast, is a steep gravity gradient indicative of the Hurricane Fault. Although this marks the southern extent of the several-hundred-kilometer-long Hurricane Fault, the magnitude and prominence of the gradient suggests significant offset and (or) the juxtaposition of rock formations with large density differences. Together, the paleochannel gravity low and
Hurricane Fault-related gradient may influence the direction and magnitude of groundwater flow, possibly resulting in preferential flow in the southwest-northeast direction.

The gravity data are complementary to the airborne electromagnetic data (Ball, 2020) as they are sensitive to different properties of the subsurface. Both methods depend on a property contrast - a density contrast for gravity data and an electrical conductivity contrast for airborne electromagnetic data. One advantage of gravity data is the sensitivity to a property of interest - density - directly related to a hydrologic property - porosity. A second advantage is potentially greater sensitivity to property contrasts at large depths. The maximum airborne electromagnetic penetration depends on subsurface properties and may be limited, especially if conductive layers are near the surface. Gravity data are theoretically sensitive to density contrasts between alluvial fill and bedrock at great depth (thousands of meters) if data are properly reduced. The primary, and most significant, limitation of gravity data is the lack of depth resolution - a flat-lying density contrast by itself does not produce a gravity anomaly. Inverted airborne electromagnetic profiles give rich information about the subsurface and are particularly effective for delineating stratigraphy in the study area between units that have little or no density contrast.

\section{References Cited}

Ball, L.B., 2020, Major hydrostratigraphic contacts of the Truxton basin and Hualapai Plateau developed from airborne electromagnetic data, northwestern Arizona, chap. D of Mason, J.P., ed., Geophysical surveys, hydrogeologic characterization, and groundwater flow model for the Truxton basin and Hualapai Plateau, northwestern Arizona: U.S. Geological Survey Scientific Investigations Report 2020-5017, 24 p., https://doi.org/10.3133/sir20205017BD.

Bills, D.J., and Macy, J.P., 2016, Hydrologic framework and characterization of the Truxton aquifer on the Hualapai Reservation, Mohave County, Arizona (ver. 2.0, December 2017): U.S. Geological Survey Scientific Investigations Report 2016-5171, 50 p., https://doi.org/10.3133/sir20165171.

Hamblin, W.K., 1970, Structure of the western Grand Canyon region, in Hamblin, W.K., and Best, M.G., eds., The western Grand Canyon district - Guidebook to the geology of Utah: Utah Geological Society, no. 23, p. 3-37.

Hinze, W.J., Aiken, C., Brozena, J., Coakley, B., Dater, D., Flanagan, G., Forsberg, R., Hildenbrand, T., Keller, G.R., Kellogg, J., Kucks, R., Lee, X., Mainville, A., Morin, R., Pilkington, M., Plouff, D., Ravat, D., Roman, D., UrrutiaFucugauchi, J., Véronneau, M., Webring, M., and Winester, D., 2005, New standards for reducing gravity data-The North American gravity database: Geophysics, v. 70, no. 4, p. J25-J32. 
Hirschberg, D.M., and Pitts, G.S., 2000, Digital geologic map of Arizona-A digital database derived from the 1983 printing of the Wilson, Moore, and Cooper 1:500,000-scale map: U.S. Geological Survey Open-File Report 00-409, 67 p., 3 sheets, and digital data.

Hwang, C., Wang, C., and Lee, L., 2002, Adjustment of relative gravity measurements using weighted and datum-free constraints: Computers and Geoscience, v. 28, p. 1005-1015.

Ivanich, P.A., and Conway, B.D., 2009, Preliminary estimate of groundwater in storage for the Hualapai Valley groundwater basin, Mojave County, Arizona: Arizona Department of Water Resources Hydrology Division Open-File Report no. $11,61 \mathrm{p}$.

Kennedy, J.R., 2020, Gravity data from the Truxton area, northwestern Arizona: U.S Geological Survey data release, https://doi.org/10.5066/P9ONSNAH.

Knight, J.E., 2020, Simulation of groundwater-level changes from projected groundwater withdrawals in the Truxton basin, northwestern Arizona, chap. E of Mason, J.P., ed., Geophysical surveys, hydrogeologic characterization, and groundwater flow model for the Truxton basin and Hualapai Plateau, northwestern Arizona: U.S. Geological Survey Scientific Investigations Report 2020-5017, 39 p., https://doi. org/10.3133/sir20205017E.

Mason, J.P., Bills, D.J., and Macy, J.P., 2020, Geology and hydrology of the Truxton basin and Hualapai Plateau, northwestern Arizona, chap. B of Mason, J.P., ed., Geophysical surveys, hydrogeologic characterization, and groundwater flow model for the Truxton basin and Hualapai Plateau, northwestern Arizona: U.S. Geological Survey Scientific Investigations Report 2020-5017, 9 p., https:/doi. org/10.3133/sir20205017B.

Mickus, K.L., and James, W.C., 1991, Regional gravity studies in southeastern California, western Arizona, and southern Nevada: Journal of Geophysical Research, v. 96, no. B7, 12333-12350.

Mira Geoscience Ltd., 2019, VPmg inversion software version 9.2 and Geoscience Analyst 2.7 software: Westmount, Quebec, Canada, Mira Geoscience Ltd.

National Geodetic Survey, 1999, Gravity station data for the U.S.: National Geodetic Survey GRAVCD-ngs99, 1 CD-ROM.

Natural Resources Consulting Engineers, 2011, Evaluation of the Peach Springs groundwater supply, Hualapai Indian Reservation: Natural Resources Consulting Engineers, 102 p.
Nielson, J.E., Lux, D.R., Dalrymple, G.B., and Glazner, A.F., 1990, Age of the Peach Springs Tuff, southeastern California and western Arizona: Journal of Geophysical Research, v. 95, no. B1, p. 571-580.

Petros Eikon, Inc., 2018, QCTool software version 3.10: Orangeville, Ontario, Canada, Petros Eikon, Inc.

Richard, S.M., Reynolds, S.J., Spencer, J.E., and Pearthree, P.A., 2000, Geologic map of Arizona: Arizona Geological Survey, scale 1:100,000, accessed January 17, 2020, at http://repository.azgs.az.gov/uri_gin/azgs/dlio/1705.

Richard, S.M., Shipman, T.C., Greene, L., and Harris, R.C., 2007, Estimated depth to bedrock in Arizona: Arizona Geological Survey Digital Geologic Map 52, version 1.0, 8 p., 1 sheet, design scale 1:1,000,000.

Saltus, R.W., and Jachens, R.C., 1995, Gravity and basindepth maps of the Basin and Range Province, western United States: U.S. Geological Survey Geophysical Investigations Map 1012, 1 sheet, scale 1:2,500,000.

Sweeney, R.E., and Hill, P.L., 2001, Arizona aeromagnetic and gravity maps and data - A web site for distribution of data: U.S. Geological Survey Open-File Report 01-0081, version 1.0, accessed August 20, 2018, at https://pubs.usgs.gov/ of/2001/ofr-01-0081/html/az iso.htm.

Telford, W.M., Geldart, L.P., and Sheriff, R.E., 1990, Applied Geophysics ( $2 \mathrm{~d}$ ed.): London, Cambridge University Press, $792 \mathrm{p}$.

Truini, M., Beard, L.S., Kennedy, J., and Anning, D.W., 2013, Hydrogeologic framework and estimates of groundwater storage for the Hualapai Valley, Detrital Valley, and Sacramento Valley basins, Mohave County, Arizona: U.S. Geological Survey Scientific Investigations Report 2012-5275, 47 p., https://doi.org/10.3133/ sir20125275.

Tucci, P., Schmoker, J.W., and Robbins, S.L., 1982, Boreholegravity surveys in basin-fill deposits of central and southern Arizona: U.S. Geological Survey Open-File Report 82-473, $24 \mathrm{p}$.

U.S. Geological Survey, 2017, About 3DEP products and services: The National Map 3D Elevation Program web page, accessed December 3, 2018, at https://nationalmap. gov/3DEP/3dep_prodserv.html.

Young, R.A., 1999, Geomorphic, structural, and stratigraphic evidence for Laramide uplift of the southwestern Colorado Plateau margin in northwestern Arizona: Utah Geological Association Publication no. 30, p. 227-237. 
Menlo Park Publishing Service Center, California

Manuscript approved for publication February 19, 2020

Edited by Monica Erdman

Layout and design by Cory Hurd

Illustration support by JoJo Mangano 


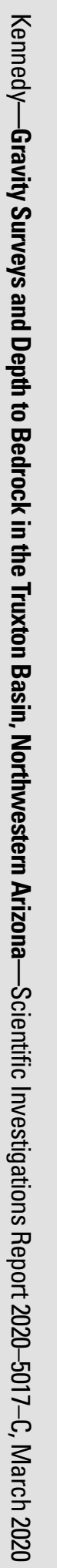

ISSN 2328-0328 (online) 